\title{
The Effect of Writer's Workshop Approach to Develop Functional Writing Skills of Primary Stage Pre-Service English Language Teachers in Egypt
}

\author{
Ashraf Atta M. S. Salem \\ $\mathrm{PhD}$ in TEFL, Institute of Educational Studies\& Researches, Cairo University, Egypt \\ E-mail: sirashrafams@hotmail.com
}

Received: 14-05-2013

doi:10.7575/aiac.ijalel.v.2n.5p.70
Accepted: 18-06-2013

Published: 01-09-2013

URL: http://dx.doi.org/10.7575/aiac.ijalel.v.2n.5p.70

\begin{abstract}
The present study aimed at investigating the effects of using a program based on the writing workshop approach on developing functional writing skills of pre-service teachers of English in Hurgada faculty of Education. For that purpose, the researcher constructed and validated a teaching program based on the writing workshop approach, checklist of the skills and subskills of functional writing skills, and pre-posttest of functional writing skills. The sample of the study was forty students in Hurgada faculty of Education, English Division (prospective teachers of English). They were randomly chosen and assigned to an experimental group. The experimental group students were taught writing using the writing workshop approach after they had functional writing skills pretest. Findings of the study indicated the writing workshop-based program had significant effects on improving the subjects' functional writing skills.
\end{abstract}

Keywords: Writer's Workshop, functional writing skills, pre-service teachers of English

\section{Introduction}

Writing as one of the four basic language skills, is given a unique importance. The value of writing is confirmed by research. That shows its value for academic as well as occupational purposes. Writing is a valuable tool for communicating one's thoughts to others. It helps to both promote the sense of ownership and express his inner feelings. Writing is the commonest way of assessing students' performance in English especially in the Arab countries (Salem, 2008).

Al-Saleem (2008, p.77) emphasizes that writing is an essential component of classroom activities as it reinforces grammatical structures and vocabulary. He also adds that writing helps students to express themselves and provide their ideas without being pressured by face-to-face communication. This was affirmed by Helal (2003, p.18) who states that challenging writing activities add variety to writing instruction and develop writing instruction and develop important literacy skills. Gracey (2004, p.53) maintains that English writing development is strongly enhanced when instruction is explicitly designed to address students' needs and objectives. Writing is one of the main important devices for people to express themselves, to shape ideas, to persuade and convince others. Elizabeth $(2004$, p.295) affirmed that whatever is written once remains forever; unless it is destroyed. She also confirmed that without the writing aspect, learning of a language remains incomplete.

Writing now is no longer relegated to second place. Instead, writing is given its own status in the ELT course. There are a number of reasons for this. For one thing, linguists have become interested in studying the characteristics of written as well as spoken language, and it is now clear to everyone that writing is not simply a poor relative of speaking - or that speaking is merely a sloppy version of writing. For another, there has been an increasing concern with the need to teach writing since it is a useful tool for practice exercises and reinforcement of academic skills. Writing itself has primary value as a language teaching tool (Abolyosr, 1996, p.15).

Writing workshop is student- centered approach to teach writing in a social context. Students learn in an environment that employs modeling and coaching where the teacher is a guide and facilitator of students learning .Typically, there is a mini-lesson at the beginning followed by stages of writing and rewriting after which students come to a sharing time to celebrate their work (El Said, 2006, p.17).

Aly (2002,p.131 as cited in El Said, 2006) concurs that writing Workshop is an approach to writing where students spend larger time engaged in compositions and select topics of personal relevance. In a writing workshop, writing is also guided through many social activities that require students to explain their ideas, develop their thoughts, or even defend theirs before the teacher and their colleagues.

\subsection{Introducing the Problem}

A review of literature of research on writing workshops suggests several conclusions. First, there is adequate evidence to support the assertion that the teaching of the writing process is a valuable practice. While the writing process is the actual material to be taught, the writing workshop can be viewed as a way of approaching the task of teaching writing and organizing it, feel confident and be initiative. Secondly, the establishment of the writing workshop can take risk in front of their teachers since there is no prescribed sequence for teaching skills and strategies. Thirdly, the abundance of 
qualitative research (and lack of quantitative research) is due to the nature of the topic studied. The cyclical nature of the writing process and the writing research approach parallels the dynamic characteristic of qualitative research. Lately, writing workshops, when implemented in their ideal form, take a large portion of the instructional day.

Primary stage Pre-service teachers of English need to develop their writing skills in general. This is due to three main reasons; first, they are prospective teachers of English so that they may teach their pupils how to write paragraphs and essays. Secondly, they need to take tests in other subjects like novels, poetry and drama so they need to write essays correctly. Thirdly, they are to be divided in their third year so it is a must to develop their writing skills in their third and fourth year. They have only two years of actual English study. Writing workshop is a student-centered approach rather than a teacher-centered approach. So, it can achieve good results when used in class in teaching writing.

The results of the pilot study (conducted by the researcher and validated by a jury) showed a very low level in writing and a need for training in functional writing skills in particular. To the knowledge of the researcher, as yet no detailed research findings are available about functional writing skills of the primary stage prospective teachers of English.

Accordingly student-teachers lack the necessary writing skills in general and functional writing skills in particular. This was manifested through the pilot study and the observations of the researcher. A need is urgent for training programs to develop these skills.

The researcher noticed that pre-service teachers of English lack the functional writing skills. They seek to convey all the information of the text without making use of the necessary functional skills for this process. So, the researcher tries to investigate the effectiveness of a proposed program based on using writing workshops in writing for developing functional skills needed for these students.

They suffer greatly when they are asked to achieve a writing task. This is manifested in their written pieces in the pilot study as it is clear that they lack the fundamental writing skills in general as well as the functional writing skills. This is the reason which makes them reluctant to write in English even it is vital to achieve tasks they need in the everyday life. Students of the English Department at the Faculty of Education need writing for many reasons. For one thing, as undergraduates they need to write term papers and articles in English. They are asked to answer essay questions in different subjects such as novel, drama, poetry, etc. For another, they need to take notes in English at lectures, talks and when reading. Finally, as prospective teachers they need to write lesson plans, summaries, reports, short pieces of narrative, simplification of a passage to suit learners of a certain level.

1.1.1 Questions of the Study

The present study tries to answer the following main question:

What is the effectiveness of the proposed program based on using workshops in developing the functional skills of writing for the third year primary pre-service teachers of English?

1.1.2 Hypotheses of the study

The study tires to test the following main hypothesis:

There is a statistically significant difference between the mean scores of the experimental group on the functional writing skills pre-test and post-test in favour of the posttest.

\subsection{Significance of the study}

This study is of special importance for the primary stage prospective teachers of English for the following considerations:

a. The study provides third year pre-service teachers of English with practical guidelines for their present and future study in the faculty of Education.

b. The significance of the study also stems from the broad aim of the program to facilitate writing process in English which these students are apt to encounter during their study at university (literature, linguistics, English Language etc.) in a way that enhances their study skills.

c. The study helps primary stage prospective teachers of English establish the right writing habits in order to teach them appropriately to their future students.

d. It is also hoped that this program will be a step in the development of training courses for teaching other writing skills to primary stage pre-service teachers of English at the faculties of Education.

1.3 Delimitations of the study

The study is limited to measuring the effectiveness of using a proposed functional writing program based on using workshops in developing the functional writing skills of primary stage pre-service teachers of English.

The skills treated in the present study are the functional writing skills and their sub-skills agreed upon by specialized jury members. The instructional time of the program devoted for the experimental group lasts for eight weeks, two meeting a week, two hours a meeting.

1.4 Definition of Terms

1.4.1 The Writing Skills

Mahran (2000:7) defined the writing skill as "the ability of producing the language in writing intelligibly, easily, expertly and well."

In the present study, the writing skill is defined as the ability to express oneself through writing in an organized and intelligible way producing sufficient content and using suitable words, correct structures, and proper conventions.

1.4.2 The Writing Workshop

El Said (2006, p.12) defined writing workshop as a student-centered approach to teaching writing in a social context. Students learn in an environment that employs modeling and coaching where the teacher is a guide and facilitator of students' learning. Typically, there is a mini-lesson at the beginning followed by stages of writing and rewriting after which students come to a sharing time to celebrate their work. 
Massengill-McLeod (2001, p.15) defined the writing workshop as "an organizational approach to writing in the classroom that supports the recursive nature of writing by adapting a process approach."

For the present study, the researcher defines writer's workshop as a process-based approach for teaching writing in a meaningful environment. It helps to teach writing in a social context. Students enjoy celebrating their work with othersin an author's chair- after modeling, peer conferencing and tender teacher guidance. Ideally, a writer's workshop begins with a mini-lesson followed by actual writing time and finally a celebration with the final product.

This definition highlights:

1. The active role of the learner as the focus of learning.

2. The role of the teacher as a guide and a facilitator.

3. The social nature of writing.

4. The recursive rather than the linear nature of the writing process.

1.4.3 Functional Writing

Unlike other approaches to teaching language, the functional approach is a model of performance. It is concerned with the functions, and language in use. It is an important tool for interpreting texts. According to Halliday (1994), the functional approach has the following three characteristic features:

1. It is based on systemic theory: Systemic theory is a theory of meaning as choice. It means starting with most general features and proceeding step by step so as to become even more specific.

2. It is functional in three distinct: First, it is concerned with the way language is organized to fulfill communicative functions. Second, it aims to account for three basic kinds of meaning, the ideational, the interpersonal and textual. Third, each element in a language is explained by reference to its function in the total linguistic system.

3. It is discourse approach. It aims to provide two levels of discourse analysis: the first is the understanding of the text. The second is the evaluation of the text.

Hartnett (1997) focuses on the importance of using the functional approach to teaching language in general and writing specifically. He argues that functional approach to teaching writing achieve communication within writing. Functional writing approach ensures using language to achieve certain purposes, it entails using language meaningfully. He concurs that:

When it comes to teaching students how to correct errors in mechanics and usage, English composition teachers have a problem determining what and how to teach. If they diligently teach grammar and punctuation by rules and teach spelling and vocabulary by lists to memorize, the intellectual work has some merit, but little of the effort transfers to writing. If teachers assign exercises made up of lists of sentences with someone else's errors to be corrected, the sentences lack a context for meaning and are therefore literally meaningless; students may try to guess, but they have no understanding or motivation to do so.

In the researcher's point of view functional writing skills as those skills needed for the routine of daily life. These skills include letter writing, report writing, writing biography, and outlining. These skills are urgent to be known as everyone uses and practices in their transactions.

\subsection{Relevant Scholarship}

Many studies have been conducted to design training programs in writing for pre-service teachers as a way of developing writing in general and functional writing in particular. Some of these studies were mainly dictated to assess the effect of teaching functional writing skills in general on the students' performance in writing.

1.5.1 Relevant Literature

Certain studies focused on the usefulness of using writer's workshop on developing functional writing skills. One of these studies was the study conducted by Oliver (1995) conducted a study in order to investigate the impact of using writer's workshop approach of eight graduate students working toward doctorates in clinical physiology. There are three goals the workshop exercises were designed to accomplish :(1) getting students' concern about their writing "normalized";(2) getting their functional technical writing skills improved;(3) their motivation to learn about technical writing increased. After the workshop, students reported that they were relieved to know they were not the only ones with concerns about writing. Findings suggest that the Action Plan implemented was successful in increasing writing fluency. On four dimensions of writing fluency, both first and second grade students not only increased the amount of words written, but also elaborated on the content itself. Given this increase; students also show effective use of vocabulary,; therefore, their writing sequence also increased. Results show that students also expressed increased enjoyment when writing.

Korbel (2001) made a program to increase the functional writing ability and improve the attitude of sixth grade students. The targeted classroom was located in a unit district 45 miles northwest of a large metropolitan area. The district's population consists of a large amount of minority students and low-income families. Evidence of the problem was established through a student survey, teacher questionnaire, and student writing samples. Analysis of probable cause data indicated that there are three possible reasons of the lack of functional writing skills. The school environment lacked curriculum, time allotment, and sufficiently trained staff members. No parent model and increased technology and time constraints were daily influences. The students themselves contributed to the deficiency due to their lack of interest, low expectation, and fear of difficulty. A review of the solution strategies, suggested by other experts in the field combined with an analysis of the problem setting, resulted in the development of a safe environment that would promote a positive attitude toward writing, devoting time daily to provide a multitude of writing experiences, and minilessons that would be target specific writing weaknesses. Post intervention data indicated positive gains in writing capabilities, increased ability to self-monitor and evaluate, and a more positive attitude toward s the writing process. 


\subsubsection{The writing workshop}

The writer's workshop approach is a relatively new technique for writing that invites students to do writing tasks in a meaningful and enjoyable way. According to this approach, students are introduced to the writing process from their early childhood through writing various activities.

According to Landry (2000), writer's workshop is an approach that makes students aware of the conventions of writing. This approach is not restricted on making students learn using sound grammar and punctuation, it also helps to learn and appreciate the importance of other steps of the writing process; drafting, revising and editing their writing. It is also argued -according to Nancie Atwell (as cited in Landry, 2000, p.4) - that writer's workshop is an "authentic" approach as it urges students to write about things important to them and are closely related to their interests, just as professional writers do.

1.5.3 Structure of the writing workshop

The writing workshop is generally set up in three parts: mini-lesson, activity time and whole class share (Calkins, 1983; Graves, 1983; Samway, 1992; Peyton et al., 1994; Preston, 2000; Wyse et al., 2001). The following lines address these parts in some detail:

1.5.3.1 Mini - Lesson

Mini-lesson is the first step in the writer's workshop which allows teachers to deliver a short lesson to make students aware of the targeted skills to be better writers. Practitioners always begin their writing workshops with mini-lesson. Mini-lesson gathers the whole class, it presents a brief lesson. If it is longer than this, it becomes a maxi-lesson. Minilesson gives students a perfect writing model to be imitated.

Bensichek, et al. (2001, p.22) state that during the five minutes of writer's workshop, mini-lessons pull students together, usually to teach skills that have come up within the student's daily writing. During the mini-lessons, teachers make their students aware of their intentions. Students are interested in working alone thus they are engaged deeply in their self-sponsored work. After that, teachers aggregate students together to give them instructions of what they are expected to do. Based on this approach, teachers are given a chance to be active meaning-makers, even during this bit of formal instruction (Calkins, 1994:193-194). Mini-lessons might focus on topics such as: use of question mark, adding on interesting details, formatting paragraphs, and proper spacing between works.

El said (2006, p.18), states that mini-lessons represent an opportunity for the teacher to show his own writing. Accordingly, modeling is essential and should be sued often, In other words, in a mini-lesson, all the class listen to the teacher and attend his modeling and coaching which they will use in their writing afterwards.

In Sum, mini-lessons are brief daily lessons that last from five to fifteen minutes at the very beginning of writer's workshop. This represents whole group instructions. The mini-lessons will be from the following categories: procedures, strategies, strategies writers use, qualities of good writing, and skills. Topics for the mini-lessons will be determines by teacher observation of students writing.

1.5.3.2 The Writing Process

The second part of any writing workshop is the actual writing process. In this part the bulk of writing takes place. During this time students write or conference with the teacher or other students. In this stage of writing workshop the children works together while the teacher moves from table to table and holds mini-conferences with the children to assess or concerns that the students might have had.

Writing process is a series of recursive stages which lead to the written product. Lucy Calkins (1983: 19) defines the writing process as "a process of dialogue between the writer and the emerging text ". Freedman, Dyson, Flower , and Chafe ( as cited in Strech, 1994 ), describe writing as a process which requires active and complex problem solving by using different procedures in a recursive manner .

1.5.3.2.1 Steps in the writing process:

1. Prewriting:

The first step in a writing process is prewriting or rather called rehearsal. In the prewriting stage the writer thinks of what he is going to do before putting pen to paper. According to Raimes ( cited in El Said 2006 ), prewriting is an important stage, as the more students struggle with the topic, the more their command of the necessary vocabulary and idiom develops. In addition, they should learn more about organizational structure and sentence structure in order to develop more ideas.

\section{Writing}

It means that the writer puts down his ideas on paper in a coherent form. Writing - as mentioned beforehand - is not linear process rather it is a recursive one, it doesn't proceed from prewriting to writing and rewriting, it goes in a circle from.

3. Revising

Revising involves going over what the student has written. It is a continuous process that is ongoing as the students proceed in their writing. According to Zemelman and Daniels (cited in Kolling, 2002, p.35), it is important to model for students the steps of revision, and equally important to help them understand the reasons revision is important. They suggest that teachers show students that revision is a normal, integral part of the whole writing process. It should not be punitive, and all ideas should be respected.

4. Editing

Editing is the stage in which the piece of writing should be without any errors. In the editing stage the student check his piece of writing for misspelling, punctuation, Capitalization and complete sentences (Wetzel, 1999, p.12). It is argued that editing means correcting level errors, normal grammar, spelling, and punctuation errors, in the final version prior to publication El Said (2006:20). 
It is a well-known fact that the more students experience language, take risk and stretch their ideas; the more likely they are to make mistakes. However, they need praise for their effort and an explanation of what they do not know rather than a reprimand for an error which actually represents growth.

\section{Peer-editing}

Experts believe that it is important for a student to receive a different perspective on their writing .Therefore, it is essential to allow to ample time for students to be engaged in peer editing. Temple (cited in Christopher, 2000, p.7), suggests away to develop a classroom environment that promotes feelings of mutual trust and cooperation to make the peer editing process successful. The first step in the peer editing process is to model what is expected from the students during this process. Another step is to provide whole class instruction focusing on a specific skill using a student writing sample .The third step is to provide cooperative group practice which allows students to look for correct and incorrect usage of the skill modeled. The final step is allowing students to peer edit with one another.

6. Whole class share

It is the final stage in the writing workshop students publishes their writing. Here students congregate together to know what each student has written and to celebrate their finished piece of writing. According to Kolling (2002), the environment in which students be one that allows a great deal of sharing. This can be done by publishing or displaying work to be read, or having their lives and stories acknowledged and celebrated. One student knows that their pieces will be published for others to view; they will take revising and editing more seriously.

Students work with the text when they copy and when they examine the writer's choices of specific linguistic and logical features, such as cohesive links, punctuation, grammar, sentence arrangement, and organization. They also work from the text when they use it to create a text of their own, that is, when they summarize, complete, speculate, or react.

7. Author's chair

When students participate in Author's chair, they share their writing and receive feedback, not only from the teacher, but from their peers. Students receive praise and take suggestions for their next writing piece. During the author's chair time, each student chosen to chair a writing piece reads his selected piece to the entire class.

As students listen to follow authors, they develop the skill of constructive criticism. They may be inspired to experiment new writing genres. In addition, students may gain insight in to their classmate's personal lives, which can enrich understanding and enhance classroom environment (Benischek, 2001).

8. Conferences

A writing Conference is a teacher and child meeting to discuss the child's writing (Calkins, 1986).According to Grave (1991: 89) a writing Conference is a meeting between the teacher and child during which the following questions are discussed: 1) Where did the piece come from? 2) Where is the piece now? And 3) Where will the piece be going?.

Klatt (1990: 40) states that there are two types of Conferences to be conducted during the writing workshop; the first type is the informal Conferences between students and teachers. The second type is the formal Conferences between the teacher and small group of children.

During Conference time, teacher should help students to stretch words, feel confident so as to continue writing on their own. Conferences are so important to assess the progress children have achieved. It is worth noting that during a conference, the teacher grants their students to talk freely about their writing. During Conference time, teachers should give students opportunities to vocalize problems they face during the writing process (Landry, 2000: 8).

According to Graves (cited in Landry, 2000), the most difficult part of the conference is not restricted on using sound punctuation, it goes further to deal with the potential of the students as proficient writers. The teacher's role here entails teachers to listen carefully to the pieces of writing produced by their students, and think about the content and style of writing they are using.

1.5.4 The roles of the teacher and students in the writing workshop

The roles of the teacher and students in the writing workshop are totally different from his role in any other approach to writing instruction. In the writing workshop, the teacher works as an informed facilitator and guide his students.

On the other hand, Stewig (cited in Korbel, 2001), states that in the writing workshop, the teacher's main objective was to drew out the child's writing ability. The philosophy of the writing workshop entails that all children can write, teachers must supply a supportive atmosphere and topics, and mechanics. Through the process of editing, teachers should increase the students comfort therefore; students are not penalized for incorrect spelling, poor sentence structure, or lack of indentation. According to Kolling (2002), teachers must be aware of how to evaluate students work effectively. Therefore, teachers perform roles such as; modeling and coaching, Responding to pieces of writing, handing students' errors and Organizing the class for writing.

\subsubsection{Benefits of writing Workshop}

Implementing writer's workshop in ELT classroom proves to be effective in developing English Language Skills. Kieczykowski (1996), states that teachers who have incorporated daily writing workshop into their curricula have note the following significant benefits; it increases self-esteem, it thrives student empowerment, it provides a risk-free environment, it helps to raise phonemic awareness, it increases fluency in reading and writing, and it provides opportunities for development of oral and written language conversation.

\section{Method}

The current study aimed at investigating the effect of the writing workshop approach on developing the functional writing skills for third year primary stage prospective teachers of English. To achieve this aim, the researcher constructed the following tools:

1. A program for teaching functional writing skills based on the writing workshop approach.

2. A checklist that was used to determine these functional writing skills and conventions of writing necessary for them. 
3. A writing test that was used in assessing students' functional writing skills.

The researcher adopted the Quasi-experimental research design which is suitable for the objectives, sample and tools of the study.

\subsection{Participants and setting of the study}

The population of this study was third year primary stage primary stage prospective teachers of English at Hurgada faculty of Education. They studied English as a subject for eight years beginning in fourth-year primary. The sample of the study consisted of forty students which were randomly chosen from the amongst the students in Hurgada faculty of Education. The number of students was forty students. The students chosen for this study were assigned to Hurgada faculty of Education on the basis of their geographical residency alone regardless of their achievement level or socioeconomic background.

2.2.1 Sample Size, Power, and Precision

The third year primary stage prospective teachers of English, Hurgada Faculty of Education were chosen for experimentation for the following considerations:

1. The third year primary stage prospective teachers of English, Hurgada Faculty of Education are still studying in the faculty of Education so they will benefit from the program in their university study. They are studying Literature (novel, drama and poetry) and also TEFL methodology in English and they need to write well in English. Therefore, a program in writing will help them greatly to develop their writing skills.

2. As they are students-teachers they are practicing teaching in their university year's study, so they may use the skills they acquired to develop their pupils writing skills.

3. Also they are going to graduate and to work in the field of teaching English. Therefore, their pupils at schools may benefit from the skills they will acquire in the new writing program.

\subsection{Sampling Procedures}

The sample of the study consisted of forty students which were randomly chosen from the amongst the students in Hurgada faculty of Education. The researcher paid a due attention to the homogeneity of the sample of the study according the following:

2.3.1 The drop-outs

The following students were excluded from the data analysis:

1. Students who were too old.

2. Students who were absent in one or more of the tests included in the study.

2.3.2 Homogeneity of the experimental group

To achieve homogeneity of the experimental group, the following variables were controlled:

1. Age

The ages of the students were obtained from the faculty records, calculated and counted in months. Days less than fifteen were omitted. Fifteen days or more were counted a month. Thus, excluding too old, the ages of the students ranged from twenty to twenty one years.

2. Socio-economic background

The subject of the study represented the majority of the inhabitants of the area in which the study was conducted and they reflected the same socio-economic background of that area.

3. Teacher

The subjects were taught by the same teacher rather than the researcher so as to eliminate the subjectivity of the researcher.

\subsection{Research Design}

2.4.1 Aim of the experiment

The experiment of the study aimed at testing the effect of the writing workshop program on the third year primary stage prospective teachers of English, Hurgada Faculty of Education functional writing skills.

\subsubsection{Design of the experiment}

The one group pre-posttest design was utilized in the experiment. The study sample was randomly chosen and assigned to one group from amongst the population of third year primary stage prospective teachers of English in Hurgada faculty of Education. The subjects of the study studied the new program after they were pretested. At the end of the experiment, the functional writing test was administered. This design can be depicted as follows:

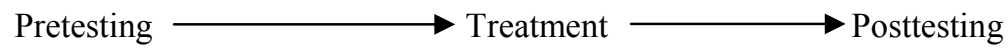

Figure (1)

Research design

2.4.3 Variables of the experiment

A. The independent variable:

The writing workshop program

B. The dependent variables

The performance of the prospective teachers of English concerning the functional writing skills. 
2.5 Experimental Manipulations or Interventions

2.5.1 The writing workshop program

2.5.1.1 Aims of the program

The program aimed at developing the functional writing skills and writing conventions for the third year primary stage prospective teachers of English. It was based on the writing workshop approach. This constituted an attempt at changing the traditional teaching/learning environment of writing instruction that resulted in poor writing performance of the third year primary stage prospective teachers of English, , Hurgada Faculty of Education which, by turn, hindered the development of their writing skills. Based on this general aim of the program, the general objectives related to the units in the program were determined.

2.5.1.2 Designing the program

In designing the program, the following steps were followed:

a. Defining objectives of the program. The behavioral objectives of the program were defined in the light of the previously defined subskills of functional writing. General objectives related to each unit as well as specific objectives of every lesson were defined. Taken into consideration was the inclusion of the three types of behavioral objectives affective, cognitive and psychomotor - into each lesson.

b. Identifying writing subskills. The functional writing sub skills that are necessary to upgrade the writing ability of the third year primary stage prospective teachers of English, Hurgada Faculty of Education were identified. For this purpose, a review of related literature was undertaken, including previous studies dealing with writing pedagogy, the course assigned for the third year primary stage prospective teachers of English, Hurgada Faculty of Education by the faculty of Education, the viewpoints of some EFL specialists (university professors, lecturers and instructors), as well as course descriptions of some writing syllabi.

c. Identifying functional writing skills. The different functional writing skills that should be mastered by third year primary stage prospective teachers of English were identified; the researcher consulted the related literature, as well as EFL specialists. As a result, the units that formed the content of the program included:

- Writing a biography. - Writing an outline.

- Writing a report. - Letter writing.

d. Deciding on the teaching strategy. The teaching strategy and activities utilized in teaching the program were identified. As the program is based on the writing workshop approach, the researcher followed the model of the writing workshop approach. This model consists mainly of three stages which formed the frame of each lesson in the program.

2.5.1.3 Program structure

Based on its defined objectives and on its teaching strategy, the program included two parts:

a) A Teacher's Guide

b) A Student's Workbook

A. Description of the Teacher's Guide

The teacher's Guide aims at providing English teachers with the information needed for the best implementation of this writing workshop program. It includes:

1. Objectives of the teaching sessions. Making the teachers aware of the objectives of each teaching session helps to achieve these objectives and invests in the meaningfulness of the activities designed. Taken into consideration is the inclusion of the three types of learning objectives - affective, cognitive and psychomotor - in every lesson.

2. Material for mini-lessons. This material provides the theoretical background necessary for enabling teachers as well as students of performing the activities and techniques on a sound basis. It provides definitions and basic information about different writing features included in the program and provides guidelines for monitoring performance as well.

3. Teaching guidelines. These guidelines tell teachers what steps to follow to best perform the proposed activities. These instructions are not meant to be followed literally, but rather are general guidelines that can be adjusted in accordance with the circumstances of the teaching/learning environment and the progress students make.

4. Timing. The Teacher's Guide also provides the teacher with a detailed schedule of the time needed for carrying out each activity. This might help the teacher monitor his pace during the sessions.

5. Answers to the evaluation exercises. At the end of each lesson in the Student's Workbook there are some questions for immediate evaluation of the session. The Teacher's Guide provides the teacher with answers to these questions to be at his immediate reach.

B. Description of the Student's Workbook

The Student's Workbook was designed to help the students practice various writing tasks which the program aimed to develop. It includes:

1. Activities for writing practice. The choice of these activities was based on the following criteria:

a. Appeal: The chosen activities provide the element of interest and appeal for the students as indicated by the members of the jury as well as by piloting.

b. Linguistic appropriateness: The activities fall within or little above the linguistic level of the students.

c. Cultural suitability: The chosen activities do not include anti-cultural values, i.e. they are suitable for the sociocultural values of the students.

2. Instructions. These instructions tell the students what they should do in every activity so as to help the development of their writing skills.

3. Spaces for carrying out tasks. According to the nature of each activity, appropriate spaces were provided for the students to carry out writing tasks freely. 
4. Evaluation exercises. Based on the behavioral objectives of each session, there are some evaluation exercises at the end of each lesson for assessing the progress students make, i.e. the extent to which they understand and can perform various tasks and techniques.

\subsubsection{Validity of the program}

To judge the validity of the program, it was submitted to a jury of university faculty members to decide on:

1. Appropriateness of the program for developing the writing skills of prospective teachers of English

2. Pertinence of the behavioral objectives of every lesson to the general aim of the program.

3. Suitability of the materials and activities presented to the objectives set for every lesson.

4. Appropriateness of the materials and activities for the linguistic and cultural level of prospective teachers of English.

The jury members appraised the program as being valid and suitable for the purpose it was designed for. Yet, they recommended certain suggestions which the researcher yielded. The researcher adapted the suggestions in the final form of the program. Thus, the program was ready for piloting and implementation.

\subsubsection{Piloting the program}

a. Objectives of piloting the program

The pilot study of the program aimed at:

1. Testing the applicability of the materials included and the activities set for teaching.

2. Diagnosing problems that might appear and suggesting suitable solutions.

3. Deciding on the suitability of the activities and program content for the third year primary stage prospective teachers of English's level.

4. Preparing a suitable time schedule of the various activities and tasks of every session as well as the program as a whole.

To accomplish these objectives, four representative lessons of the program were administered to a randomly chosen student of English Department in Qena faculty of Education. These lessons included: a) What is a paragraph?, b) Writing a biography. These lessons were selected because they represented the core of the program as each lesson represents the unit from which it is selected. Thus, the two units of the program were represented and students were given a comprehensive picture of the whole program. The pilot study took two weeks starting on February 20, 2012 and ending on February 30, 2012.

2.5.1.6 Evaluating the pilot study of the program

Based on the objectives of piloting the program mentioned above, evaluation of the pilot study of the program was twofaceted: formative and summative.

a. Formative evaluation which occurred during the implementation of the pilot study. It was based on the observations of the researcher as well as the feedback received from the students. Based on the formative evaluation of the pilot study, some changes were introduced in the initial form of the program.

b. Summative evaluation which occurred by the end of the pilot study.

2.5.2 The functional writing pre-posttest

\subsubsection{Aim of the test}

The aim of the test was to assess the effect of the writing workshop approach on developing third year primary stage pre-service teachers of English functional writing skills. More specifically, the test was used to compare pre-service performance in functional writing skills of the subjects of the study who were taught writing utilizing the writing workshop approach in the pre and post testing.

2.5.2.2 Description of the test

The test was divided into four parts as follows (see Appendix E, page 302):

Part (1): Writing a biography.

Part (3): Writing a report.

Part (2): Writing an outline.

Part (4): Letter writing.

These parts represented the core of the program. Designing the test was based on reviewing pertinent viewpoints of EFL specialists and reviewing related literature.

2.5.2.3 Validity of the Pre-post Test

To judge the validity of the writing performance test, the researcher used two ways.

a. Validity by Jury Members

The test was submitted to a jury to decide on:

1. Clarity of test instructions.

2. Suitability of test items for assessing the functional writing skills of the third year primary stage prospective teachers of English students.

3. Suitability of test items for the third year primary stage prospective teachers of English students' level.

4. Suitability of the proposed scoring technique.

5. Any other comments or suggestions.

Some modifications were made in the wording of the test instructions in the light of the jury members' comments especially in those who have a psychological background. The jury members decided that the test is generally valid to be used in assessing the third year primary stage prospective teachers of English's functional writing skills.

b. Internal Consistency Validity

The researcher used the correlation coefficients between the marks of every part of the four parts that constitute the test in order to determine the validity of the test. 


\begin{tabular}{lllll}
\multicolumn{5}{c}{ Table 1. Internal Consistency Validity of the Pre-post Test of Functional Writing Skills } \\
\hline & First Question & Second Question & Third Question & Fourth Question \\
\hline The First Part & 0.651 & & & \\
The Second Part & 0.753 & 0.518 & & \\
The Third Part & 0.579 & 0.541 & 0.628 & \\
The Fourth Part & 0.729 & 0.681 & 0.719 & 0.736 \\
\hline
\end{tabular}

It is clear from the table (1) that correlation coefficients between the four parts of the test as well as the overall mark that these correlations are statistically significant at level 0.01 .

2.5.2.4 Reliability of the test

The researcher used the inter-rater reliability to determine the reliability of the test. Two raters participated in scoring the paragraphs written by students participating in the pilot study (each rater was given a separate copy of the test papers to score by himself) after they were instructed in scoring paragraphs using the scoring criteria. Scores given by the two raters were correlated using Pearson Formula. The correlation coefficient between the first and second rater is 0.943 at significance level 0.01 .

The researcher used the Split-half way in order to determine the reliability of the test. Guttmann Formula - which does not hypothesize that every part of the test is not equivalent to the other parts-, was used to calculate the reliability of the test. The test reliability coefficient was 0.85 at significance level 0.01 . Also, the researcher used Spearman-Brown Formula to determine the reliability of the test. The correlation coefficient between the score of the students for the single and double item within the test is 0.945 . It is clear then that the test is reliable.

2.5.2.5 Administration time

In calculating the time required for answering the test, the researcher recorded down the time each student in the pilot study finished answering the test. Then, time periods were averaged for the whole pilot sample. The calculated mean time was 120 minutes.

\section{Results}

\subsection{Statistics and Data Analysis}

The Statistical Package for Social Sciences (SPSS, version 17.0) was used in the treatment of the results of the study. Ttest formula was employed in analyzing students' scores on the functional writing skills test.

Conditions for utilizing $t$-test formula were actualized as follows:

Randomization of sampling: The study sample was randomly chosen and assigned to the sample of the study of third year primary stage prospective teachers of English, Hurgada Faculty of Education.

\subsection{Ancillary Analyses}

Therefore, $t$-test formula was used in the statistical treatment of the study results. The main question of the study was stated as follows:

"What is the effectiveness of the proposed program based on using workshops in developing the functional skills of writing for third year primary stage pre-service teachers of English?"

To answer this question, it was hypothesized that:

"There is a statistically significant difference between the mean scores of the subjects on the functional writing skills pre-posttest in favour of the post test."

To test this hypothesis, students' scores on the writing test were calculated and tabulated .T-test formula for independent samples was employed to decide on the significance of the difference between mean scores of the subjects in the pretest and posttest. Table (2) sets out the results of the post-testing of the students' knowledge of functional writing skills.

Table 2. $t$-test results of pre/post-testing of students 'of Functional writing skills

\begin{tabular}{cccccc}
\hline Subjects & $\begin{array}{c}\text { Number of } \\
\text { students }\end{array}$ & $\begin{array}{c}\text { Mean } \\
\text { score }\end{array}$ & $\begin{array}{c}\text { Standard } \\
\text { deviation }\end{array}$ & $\begin{array}{c}\text { Observed } t \text { - } \\
\text { value }\end{array}$ & $\begin{array}{c}\text { The Effect } \\
\text { Size }\end{array}$ \\
\hline Pretest & 40 & 23.5 & 10.78 & & $28.49^{*}$ \\
\hline Posttest & 40 & 76.75 & 11.67 & 0.976 \\
\hline $\mathrm{P} \leq .001$ & & & &
\end{tabular}

$$
* \overline{\mathrm{P} \leq .001}
$$

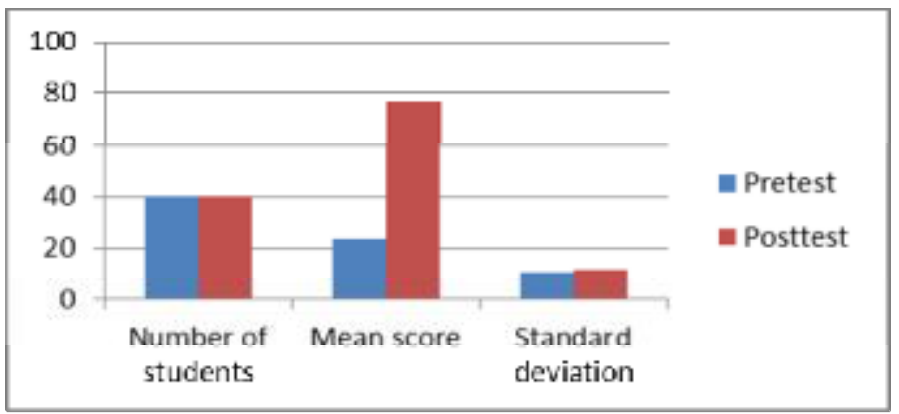

Figure 2. Means and Standard Deviations in pre/post-testing of Functional writing skills 
Close inspection of data presented in table (2) reveals that there is a statistically significant difference between mean scores of the subjects of the study in the pretest and posttest on the writing test, favoring the posttest. Therefore, the hypothesis is accepted, i.e. there is a statistically significant difference between mean scores of the subjects in the pretest and posttest on the writing posttest in favor of the posttest scores. Since the subjects share all the same variables save the new program, the significant improvement in the subjects' knowledge of the writing skills can be attributed to the effect of the new program. Hence, the writing workshop approach had a significant effect on upgrading the subject's students' knowledge of the functional writing skills.

\section{Discussion}

Results of the current study are also in line with the results of a study conducted by Klatt (1996) that examined and described a program for implementing a writer's workshop to increase the literacy skills of reading and writing. The targeted population consisted of early childhood special education, kindergarten, and first-grade students. Results of the study indicated an improvement in student writing and reading achievement. As indicated by the data, $66 \%$ of all students scored above $80 \%$ on the letter recognition test, and $89 \%$ of all students advanced to a higher stage in their writing.

The positive results of this part can be attributed to the effectiveness of the writing workshop program included in the current study, and its richness with information related to writing skills. Contrary to most traditionally-based teaching of writing, in this program each session began with a mini-lesson in which the teacher gave a theoretical introduction to provide the students with the information required in every lesson. In this part also, the students had the chance to listen to their teacher, ask about and discuss any point they could not understand. At the end of each mini-lesson, the teacher helped the students to take notes in their workbooks about the important points of the lesson. Thus, this feature of the program was a rich source of knowledge and information related to writing skills. It empowered them with the information necessary for improving their writing skills and for getting ready for the final tests of the program as well.

Moreover, the improvement in the knowledge of writing skills can be attributed to the discussions and exchanges taking place through the different stages of every session. During the writing conferences that took place, there were many chances to exchange ideas and discuss certain areas of interest. These discussions and exchanges consolidated the acquisition of this knowledge and, furthermore, provided many new items for the students. In addition, the practical nature of the activities contained in the program helped the students to get new concepts through practice.

It is, thus, evident that the new program had a substantial effect on improving the students' knowledge of writing skills. As a result, the first hypothesis; "There is a statistically significant difference between mean scores of the subjects in the pretest and the posttest on the functional writing test. This difference is in favor of the posttest scores." is accepted.

\section{Conclusions}

The results of this study can be attributed to the effectiveness of the writing workshops in developing the students' functional writing skills. This effectiveness is the result of many aspects of the proposed methodology that are absent in the Egyptian context. These aspects were represented in the features of the new program that contributed to developing functional writing skills of the students. For instance, the systematic instruction provided in the program had a substantial effect on the quality of writing. In addition, the help provided by the teacher during the sessions time and the exchanges that took place between the teacher and the students as well as among the students themselves were influential in improving students' writing. Furthermore, the classroom environment as a whole was of a crucial importance in improving the students' writings.

The in-depth analysis of basic writing components revealed that there are significant differences between the subjects in the pre and posttest. These differences are in favor of the subject's post test scores in all components. This gain in this area might be attributed to the systematic instruction and training in observation skills. The participants were trained in using the various writing stages and also using each stage techniques as the prewriting techniques. Also, those students were provided with many chances in which they experienced with varied topics, both pre assigned topics and topics of their own choice. Moreover, the ideas-generation techniques, such as brainstorming, free writing, and journalist's questions, were very effective in providing the students with the required details. Furthermore, the concentration of the researcher throughout the different stages of each session on the idea that students can benefit from each other and add to or improve their ideas at any stage resulted in the overall richness of the content of their pieces. For all these reasons, the gain in the functional writing area can be attributed to the new program.

\section{Recommendations}

Based on the findings of the present study, the researcher recommends introducing the writing workshop approach to be used in teaching functional writing skills in faculties of Education. It is also recommended that giving due focus to the process writing approach to writing instruction and training students as well as teachers of English on using that approach. In addition, based on the results of the study we should introduce the notion of peer and group work into writing classes instead of the traditional view of writing as an individual activity. This entails training the students to work collaboratively with each other when writing. The writing class environment should be centered on the student rather than the teacher. In other words, when students begin to write, what the students themselves know should be stressed and teacher intervention should be kept minimal. The researcher also recommends introducing other forms of evaluation, namely self as well as peer evaluation, into writing classes prior to teacher evaluation. In addition, it is recommended that teaching functional writing skills should be given more consideration in Egyptian faculty of Education \& Arts courses in a systematic way. Also, it is recommended to center the writing class environment on the student rather than the teacher. In other words, when students begin to write, what the students themselves know should be stressed and teacher intervention should be kept minimal. 


\section{Acknowledgement}

All thanks goes to Dr. Ahmed Idrees, Lecturer of TEFL, Zagazig University. Many thanks go to Dr. Antar Solhy, Associate professor, TEFL, Taiba University. A big thank you to Dr. Ali Al Sagheer, TEFL lecturer, Sohag University. Also, my gratitude for Dr. Azza Marsfy, professor of TEFL, Zagazig University. A big thank you for Dr. Ali Madkour, Professor of Arabic Language Teaching, Cairo University.Due thanks goes to Dr. Elham Abdulhameed, professor of Curricula and Instruction, Cairo University. The biggest thank you goes to Dr. Mahmoud Al-Naka, Professor of Arabic Language Teaching, Ain Shams University. Many thanks go to my dear colleagues in the State of Kuwait. Many thanks go to my mother, wife, and daughters Malak and Nour.

\section{References}

Abolyosr, M., (1996). Designing a Program for Developing the Writing Skill: an Integrative-Interactive Approach. Unpublished PhD thesis. Qena Faculty of Education. South Valley University.

Al-Saleem, A.A. (2008). The Effect of the Whole Language Approach on Developing English Writing Skills for the First Year Secondary School Students in Saudi Arabia. Unpublished Ph.D. Thesis. Cairo University. Egypt.

Benischek, D., Vejr, M. J., Wetzel, S. (2001). Improving Written Language Skills in the Primary Grades. Master of Arts Action Research project, Saint Xavier University and skylight professional Development field -Based Master's program. Available at: http://www.eric.ed.gov.doi.461876.

Calkins, L. (1986).The Art of Teaching Writing. New Hampshire: Heinemann.

Calkins, L. M. (1994). The Art of Teaching Writing. Portsmouth, New Hampshire: Heinemann.

Christopher, N.; Ewald, M.; Giangrasso, S. (2000). Improving Inadequate Writers. MA. Research project, Saint Xavier University and Skylight Professional Development. Available at http://www.eric.ed.gov.doi.445343.

El Said, A. M., (2006). The Effect of Using A programme Based on the Writing Workshop Approach on the Writing skills and on the writing Apprehension of the second year Preparatory Student. Unpublished MA. Sohag Faculty of Education, South Valley University.

Gracey, C. (2004). Mastering the Writing Process. Available at http//:www.back2college.com/writprocess.htm Graves, D. (1983). Writing: Teachers and Children at Work. Portsmouth, New Hampshire: Heinemann.

Graves, D. (1994).A fresh look at Writing. Portsmouth. NH: Heinemann.

Halliday, M.A.K. (1994). An Introduction to Functional Grammar. $2^{\text {nd }}$ edition. London: Edward Arnold.

Hartnett, Carolyn G. (1997). A Functional Approach to Composition offers an Alternative. Composition Chronicle: Newsletter of Writing Teachers; 10(5).pp. 5-8.

Hartnett, Carolyn G. (1997). Probing your Draft: Fifty ways to Polish Your Writing. Texas City, TX: College of the Mailand.

Kieczykowski, carol (1996). Primary writer's Workshop: Developing Process Writing Skills. New Jersey: Modern curriculum press.

Klatt, Ellen (1996). Improving student reading and writing skills through the use of writer's workshop. MA. Project. Saint Xavier University. Available at http://www.eric.ed.gov.doi.398596.

Kolling, A. (2002). Improving Student Revising and Editing Skills through the Use of Peer Editing and Writing Conferencing. Master of Arts Action Research project, Saint Xavier University and Skylight professional Development field-Based master's program. Available at www.eric.ed.gov.doi. 465189.

Korbel, Teresa M. (2001). Strengthening Student Writing Skills. Master of Arts Action Research Project, Saint Xavier University and Skylight professional Development Field-Based Master's program. Available at: http://www.eric.ed.gov.doi. 454546.

Landry, Danielle (2000). Can Writer's Workshop be Successful in the First Grade? Available at: http://www.eric.ed.gov.doi.440 407.

Massengill, M. (2001). Negotiating Transitions at Risk Students Adjustment from a Middle School Reading Workshop to Traditional High School English Class. DAL, 62(5), pp.1-16.

Oliver, Peter V. (1995). Learning to Write, Writing to Learn: A Study on Process-Oriented Writing in Graduate Education. University of Hartford.

Peyton, J., K., Jones, C., Vincent, A. \& Greenbatt, L. (1994). Implementing writing workshop with ESOL students: Visions and Realities. TESOL Quarterly, 28(3), pp. 496-487.

Preston, P., A., D. (2000). Writing Workshop Revisited: A Look at Second-grade Children's Writings and Interactions. Ed.D.University of Massachusetts Amberst. Available at http://wwwlib.umi.com/dissertations/preview.all/doi.9988833. Salem, A. A. M. (2008). The Effectiveness of a Proposed Program Based on Using Workshops in Developing the Functional Writing Skills of Primary Stage Prospective Teachers of English. Unpublished MA Thesis in TEFL. Institute of Educational Studies, Cairo University, Egypt.

Samway, K. D. (1992). Writers' Workshop and Children Acquiring English as a Non-native Language (Report No. BBB 27896). Washington, D.C.: National clearinghouse for bilingual Education. Available at: http:// www.eric.ed.gov.doi. 347-832.

Stretch, L. (1994). The Implementation of Writing Workshop: A Review of the Literature. Available at http://www.eric.ed.gov.doi..380797.

Wetzel. K. (1992). Computers and Writing Process: Teacher's guide to Organizing and Evaluating Student Writing. International Society for Technology in Education.

Wyse., D. \& Jones, R. (2001). Teaching English Language and Literacy. London: Routledge Falmer. 